\title{
Artrose i Norge
}

\author{
Barbara Slatkowsky-Christensen ${ }^{1}$ og Margreth Grotle ${ }^{2}$ \\ 1) Revmatologisk avdeling, Diakonhjemmet sykehus, Oslo \\ 2) Nasjonalt revmatologisk rehabiliteringskompetansesenter, Diakonhjemmet sykehus, Oslo og \\ FORMI, Bevegelsesdivisjonen, Ullevål sykehus, Oslo
}

\section{ENGLISH SUMMARY}

Slatkowsky-Christensen B, Grotle M. Osteoarthritis in Norway. Nor J Epidemiol 2008; 18 (1): 99-106.

Osteoarthritis (OA) is a complex process affecting many different joint areas in the body. The joints most commonly affected are the knees, hips, and hands. From a patho-physiological point of view, some features are crucial for the diagnosis, such as cartilage fibrillation and thinning, subchondral sclerosis and the presence of osteophytes. The currently most widely used definitions of OA include pathogenetic features (mechanical and biological events), morphologic features (changes in articular cartilage and subchondral bone) as well as clinical features (joint pain, stiffness, tenderness, limitation of movement, crepitus and occasionally inflammation/effusion).

The features that until now have been used for diagnosis and classification are based on radiographic and/or clinical descriptions. From a clinical perspective, OA is the most prevalent rheumatic joint disorder, causing pain and stiffness of the joints and for the individual impaired function and health status. For epidemiological descriptions of prevalence and incidence of OA, radiographic criteria are the most reliable and commonly used. Definitions of radiographic OA include descriptions of cartilage thinning (such as joint space narrowing), subchondral bone involvement (sclerosis) and/or the presence and grading of osteophytes.

Although there are geographical variations in the occurrence of OA of different joint areas, OA is seen in all populations studied. The prevalence and incidence estimates show a vide variation, however. Still the epidemiological studies of $\mathrm{OA}$ are hampered by a number of factors including different definitions of the disorder, different subsets of disease, and low degree of correlation between different definitions (radiographic vs clinical).

Several highly suggested risk factors have been identified for knee OA. Several of these may be important targets for intervention or prevention, such as physical activity, body mass index, nutritional constituents and quadriceps strength. There is a need for prospective studies evaluating risk factors in hip and hand OA.

Although there are problems in studying OA epidemiologically, the available data have shown that $\mathrm{OA}$ is an extremely common and disabling disorder. Through a further development of both epidemiological and other methods of OA research, this area can continue to be exciting and rapidly developing.

Key words: Osteoarthritis, Definitions, Criteria, Treatment, Prevalence, Incidence, Risk factors

\section{DEFINISJON OG PATOLOGI}

Artrose er den hyppigst forekommende leddsykdommen i både Norge, Skandinavia og i den vestlige verden (1). Artrose eller osteoarthritis, som er det engelske begrepet, er en degenerativ leddsykdom som omfatter nedbrytning av leddbrusk, inflammasjon og forandringer i leddnære strukturer. Artrose er en tilstand som kan defineres på ulike måter, men den mest brukte definisjonen inkluderer patogenetiske faktorer (mekaniske og biologiske komponenter), morfologiske faktorer (endring i leddbruks og subkondralt ben) så vel som kliniske faktorer (leddsmerter, stivhet, ømhet, redusert bevegelighet, krepitus og inflammasjon) (2).

Etiologien bak en artroseprosess er imidlertid uavklart. Man antar at den patologiske prosessen hovedsakelig starter i brusken og at kompliserte patofysiologiske prosesser medfører brusknedbrytning, som igjen gir delvis eller fullstendig tap av brusk, synovitt, eventuelt inflammasjon $i$ andre leddnære strukturer og subkondral sklerose. En sentral teori går ut på at artrose er et resultat av en ubalanse mellom anabole og katabole mekanismer, som er mediert via proinflammatoriske cytokiner, matrix-komponenter og mekanisk stress $(3,4)$.

\section{HistorikK}

Til tross for at artrose har vært en utbredt leddsykdom helt tilbake til den Saxonianske tidsalder (fra 8. århundre) (5), ble den ikke beskrevet som i epidemiologiske studier før inntil de siste tiårene (6). Tidligere ble artrose sammen med andre revmatiske sykdommer, særlig revmatoid artritt (RA), omtalt som" gikt" eller "slitasjegikt". Kunnskapen om artrose har endret seg i de siste årene, så artrose er i dag ikke lenger "bare slitasjegikt", men betraktes som en sykdom der en inflammatorisk komponent er helt sentral (7). Endring i forståelsen av artrose og patofysiologiske prossesser har medført endringer $\mathrm{i}$ behandlingen. I dag er tverrfaglig behandling anbefalt, og det forventes nye behandlingsmetoder i fremtiden, spesielt på den medikamentelle siden (8-12) (se mer om behandling lenger nede). 


\section{KRITERIER}

De vanligste artrosetypene er artrose $\mathrm{i}$ hånd, hofte, kne og/eller rygg, og kriterier for diagnostisering og klassifisering er basert på radiografiske og/eller kliniske beskrivelser av symptomer. For hånd-, hofte- og kneartrose eksisterer det klassifikasjonskriterier (13-15), mens foreløpig finnes ingen klassifikasjonskriterier for artrose i rygg. Mens kriteriene for håndartrose baseres kun på kliniske funn som smerte, smertevarighet og lokalisajon av smerte, samt hevelse/knuter i fingrene (figur 1), så kan kriteriene for kneartrose både være rent klinisk og/eller inkludere bildediagnostikk (røntgen) (figur 2). Klassifikasjonskriteriene for hofte er en kombinasjon av kliniske funn (smerte), senkning og røntgen (figur 3).

De mest anvendte radiografiske kriteriene for artrose er kriteriene som Kellgren og Lawrence utviklet $\mathrm{i}$ Manchester, Storbritannia, på slutten av 50-tallet (16). Disse kriteriene bygger på identifisering av osteofytter, avsmalning av leddspalte og subkondral sklerose. Ahlbäck har laget radiografiske kriterier for kneet (tiberofemural ledd) i 1968 (17) som hovedsakelig har blitt brukt i Nord-Europa. Det eksisterer flere andre radiografiske kriterier, eksempelvis Altman atlas (18) for hånd (DIP, PIP og CMC ledd), hofte (acetabulum,

Figur 1. ACR Osteoarthritis Classification Criteria, Hand.

Hand pain, aching or stiffness and

at least 3 of the following 4:

Hard tissue enlargement of 2 or more of 10 selected hand joints* Hard tissue enlargement of 2 or more DIP joints Metacarpophalangeal swelling in fewer than 2 joints

* Second and third distal interphalangeal, second and third proximal interphalangeal and first carpometacarpal joints

Sensitivity $94 \%$, specificity $87 \%$

Altman R, Alarcon G, Appelrouth D, Bloch D, Borenstein D, Brandt K et al. The American College of Rheumatology criteria for the classification and reporting of osteoarthritis of the hand. Arthritis Rheum 1990; 33 (11): 1601-10.

Figur 2. ACR Osteoarthritis Classification Criteria, Hip.

\begin{tabular}{c} 
Hip pain \\
and \\
at least two of the following: \\
ESR less than $20 \mathrm{~mm} / \mathrm{hr}$ \\
Radiographic femoral or acetabular osteophytes \\
Radiographic joint space narrowing \\
(superior, axial or medial \\
Sensitivity $89 \%$, specificity $91 \%$ \\
\hline
\end{tabular}

Altman R, Alarcon G, Appelrouth D, Bloch D, Borenstein D, Brandt Ket al. The American College of Rheumatology criteria for the classification and reporting of osteoarthritis of the hip. Arthritis Rheum 1991; 34 (5): 505-14. femur) og kne (medial kompartment, lateral compartment, tibia, femur), som baserer seg på vurdering av osteofytter, leddspalte-avsmaling og erosjoner og ble validert og nylig revidert (19).

Hvilke kriterier man vil anvende avhenger naturlig nok av hensikten med diagnostiseringen/klassifiseringen, for eksempel om dette skal brukes i en klinisk hverdag eller i epidemiologiske studier. Kriterier som anvendes i forskning bør være testet ut i gode vitenskapelige studier. Per i dag er dette kun mulig for hofte, kne, og håndartrose. I tillegg snakker man ofte om generalisert artrose, som består av håndartrose samt artrose $\mathrm{i}$ andre leddregioner, spesielt i kneleddet (20). Det er imidlertid ikke enighet om dette er en klart definerbar undergruppe av artrosesykdommene. Frem til nå har ingen utviklet klare klassifikasjonskriterier for generalisert artrose, men det arbeides med dette (20).

\section{Prevalens}

Inntil nylig har prevalensen av artrose i den norske befolkningen vært ukjent (21). I 2004 ble imidlertid artrose $\mathrm{i}$ den generelle befolkningen bosatt i Ullensaker kommune kartlagt (del av Ullensakerundersøkelsen ved Bård Natvig) (22). Da svarte 3266 personer i alderen 24-76 år (svarprosent på 56,7\%) på følgende spørsmål om artrose: "Har du fått stilt diagnosen slitasjegikt (artrose) i kne, hofte eller hender av lege og/eller på røntgen?’. I dette norske utvalget var den gjennomsnittlige prevalensen for alle aldersgrupper henholdsvis 5,5\% (95\% CI: 4,7-6,3) for hofteartrose, $7,1 \%(6,3-8,0)$ for kneartrose og 4,3\% $(3,6-5,0)$ for håndartrose. Prevalensen av artrose var høyere hos kvinner enn hos menn og i de eldre aldersgruppene, spesielt etter 50 år (Tabell 1). Den totale prevalensen for artrose (der de tre kroppsregionene ble slått sammen) var 12,8\% (11,7-14,0), og den var høyere for kvinner $(14,7 \%(13,1-16,4))$ enn for menn $(10,5 \%$ $(9,0-12,1))$.

Den største svakheten med den norske prevalensstudien er at tallene bygger på selvrapportert artrose der artrosediagnosen dessverre ikke er verifisert med radiologisk undersøkelse. Dette kan ha ført til at estimatene er noe høyere enn om radiologiske kriterier ble anvendt. Ved sammenligning av resultatene fra den norske studien med andre epidemiologiske studier av den generelle befolkningen i Skandinavia (Tabell 2), så ser vi imidlertid at dette ikke ser ut til å være tilfelle. For eksempel, de norske estimatene av kneartrose er mye lavere enn i svenske studier til tross for at radiologiske kriterier ble brukt her (20-25). Noe av forskjellen kan forklares med høyere aldersgruppe i de svenske studiene. Dette bekreftes av at prevalensen av kneartrose i Finland er svært mye lavere når man gir estimater for hele populasjonen (fra $0+$ ). En oversiktsstudie har vist at det er store variasjoner i prevalensestimater for radiografisk kneartrose, fra 3,8\% i yngre populasjoner (25 til 74 år) og opptil mellom 14\% og $30 \%$ hos personer over 45 år (26). 
Figur 3. ACR Criteria for Classification of Idiopathic Osteoarthritis (OA) Knee.

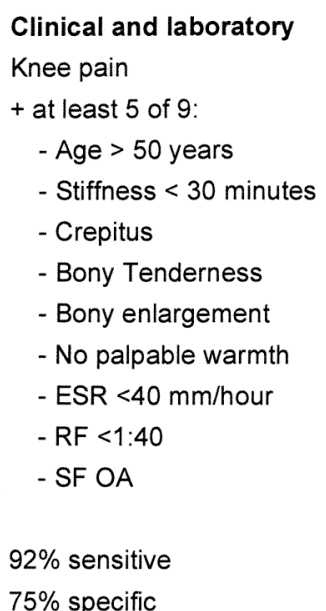

Clinicalt

Knee pain

+ at least 3 of 6 :

- Age $>50$ years

- Stiffness $<30$ minutes

- Crepitus

- Bony Tenderness

- Bony enlargement

- No palpable warmth

* $\mathrm{ESR}=$ erythrocyte sedimentation rate (Westergren); RF = rheumatoid factor; SF OA = synovial fluid signs of OA (clear, viscous, or white blood cell count $<2,000 / \mathrm{mm}^{3}$ ).

† Alternative for the clinical category would be 4 of 6 , which is $84 \%$ sensitive and $89 \%$ specific.

R. Altman, E. Asch, D. Bloch, G. Bole, D. Borenstein, K. Brandt, et al. The American College of Rheumatology criteria for the classification and reporting of osteoarthritis of the knee. Arthritis Rheum 1986;29:1039-1049.

Tabell 1 (fra Grotle et al, ref. (22), med tillatelse). Prevalens (frekvenser med prosent i parentes) av artrose i hofte $(n=179)$, kne $(n=233)$ og hånd $(n=141)$ fordelt på kjønn og aldersgrupper $(N=3266)$.

\begin{tabular}{|c|c|c|c|c|c|c|c|}
\hline \multirow[b]{2}{*}{ Aldersgruppe } & & \multicolumn{3}{|c|}{ Menn $(n=1480)$} & \multicolumn{3}{|c|}{ Kvinner $(n=1786)$} \\
\hline & & $\begin{array}{l}\text { Hofte- } \\
\text { artrose } \\
\mathrm{N}=68\end{array}$ & $\begin{array}{c}\text { Kne- } \\
\text { artrose } \\
\mathrm{N}=92\end{array}$ & $\begin{array}{l}\text { Hånd- } \\
\text { artrose } \\
\mathrm{N}=37\end{array}$ & $\begin{array}{l}\text { Hofte- } \\
\text { artrose } \\
\mathrm{N}=111\end{array}$ & $\begin{array}{c}\text { Kne- } \\
\text { artrose } \\
\mathrm{N}=141\end{array}$ & $\begin{array}{l}\text { Hånd- } \\
\text { artrose } \\
\mathrm{N}=104\end{array}$ \\
\hline $1928-1930$ & 74-76år & $23(19,0)$ & $18(14,9)$ & $6(5,0)$ & $28(21,4)$ & $37(28,2)$ & $14(10,7)$ \\
\hline $1938-1940$ & 64-66 år & $20(9,0)$ & $31(14,0)$ & $16(7,2)$ & $33(14,0)$ & $38(16,1)$ & $31(13,1)$ \\
\hline $1948-1950$ & $54-56$ år & $17(5,4)$ & $26(8,3)$ & $9(2,9)$ & $37(9,9)$ & $39(10,5)$ & $42(11,3)$ \\
\hline $1958-1960$ & 44-46 år & $5(1,8)$ & $10(3,6)$ & $5(1,8)$ & $10(3,1)$ & $16(4,9)$ & $13(4,0)$ \\
\hline $1968-1970$ & 34-36 år & $3(0,7)$ & $7(1,7)$ & $1(0,2)$ & $1(0,2)$ & $10(1,8)$ & $4(0,7)$ \\
\hline $1978-1980$ & 24-26 år & 0 & 0 & 0 & $2(1,1)$ & $1(0,6)$ & 0 \\
\hline Total & Alle & $68(4,6)$ & $92(6,2)$ & $37(2,5)$ & $111(6,2)$ & $141(7,9)$ & $104(5,8)$ \\
\hline
\end{tabular}

Selv om vi justerer for alder så er de norske estimatene for håndartrose mye lavere enn hva som er rapportert både $\mathrm{i}$ en tidligere finsk studie (fra 13-15\%) og $\mathrm{i}$ en svensk studie med estimater helt opp til 9798\% hos personer mellom 75 og 79 år (Tabell 2). Prevalensen på 4-7\% i en dansk populasjon fra 18 år og oppover er imidlertid svært like våre norske tall. Tabell 2 viser også at de norske estimatene for hofteartrose er svært like den finske studien i de samme aldersgruppene (varierer mellom 4 og 7\%). I den svenske studien var prevalensen av hofteartrose lavere, mellom 3 og 4\% (27), mens i den islandske befolkningen er den mellom 10 og 12\% (28). Denne oversikten tyder med andre ord på at det er lite sannsynlig for stor overestimering av prevalens av artrose $\mathrm{i}$ den norske studien. Allikevel burde det norske artrosespørsmålet valideres opp mot radiologiske kriterier.

\section{INSIDENS}

Artrose omtales ofte som en voksende epidemi - noe som antas å ha sammenheng med økende alder og økende forekomst av overvekt og inaktivitet (1). I en av de tidlige insidensstudiene i USA, der radiografiske kriterier ble anvendt, fant de at ca. $1 \%$ av kvinner $i$ alderen 70 til 89 år utviklet symptomatisk kneartrose per år, mens insidensen for hånd-og hofteartrose var langt mindre (29). På lignende vis som ved prevalensstudier finner man en økt insidens av artrose med alderen.

Det finnes ingen norske publiserte studier om insidens av artrose $\mathrm{i}$ den generelle norske befolkningen. Man har imidlertid tall på at insidensen av uførepensjon for artrose har økt fra 1968 til 1997, og økningen er høyere enn for uførepensjon generelt (21). 
Tabell 2 (fra Grotle et al, ref. (22), med tillatelse). Studies of prevalent osteoarthritis (OA) in population-based epidemiological studies in Scandinavia: the prevalence for OA in hip, knee, and hand, respectively, is presented in percentage with $95 \%$ confidence intervals when provided.

\begin{tabular}{|c|c|c|c|c|c|c|c|}
\hline $\begin{array}{l}\text { Country, } \\
\text { first author, year }\end{array}$ & $\mathrm{N}$ & Age & Gender & $\begin{array}{l}\text { Definition/ } \\
\text { classification }\end{array}$ & Hip OA & Knee OA & Hand OA \\
\hline \multirow{3}{*}{$\begin{array}{l}\text { Norway, } \\
\text { Grotle, } 2007\end{array}$} & \multirow[t]{3}{*}{3266} & \multirow[t]{3}{*}{$24+$} & Men & \multirow[t]{3}{*}{ Self-reported OA } & 4.6 & 6.2 & 2.5 \\
\hline & & & Women & & 6.2 & 7.9 & 5.8 \\
\hline & & & Both & & $5.5(4.7-6.3)$ & $7.1(6.3-8.0)$ & $4.3(3.6-5.0)$ \\
\hline \multirow{2}{*}{$\begin{array}{l}\text { Denmark, } \\
\text { Sonne-Holm, } 2006\end{array}$} & \multirow[t]{2}{*}{3355} & \multirow{2}{*}{$18+$} & Men & \multirow{2}{*}{$\begin{array}{l}\text { Kellgren\&Lawrence } \\
\geq \text { grade } 2\end{array}$} & & & $4.0\left(1^{\text {st }} \mathrm{CMCJ}\right)$ \\
\hline & & & Women & & & & $7.4\left(1^{\text {st }} \mathrm{CMCJ}\right)$ \\
\hline \multirow{2}{*}{$\begin{array}{l}\text { Finland, } \\
\text { Laine, } 1962\end{array}$} & \multirow[t]{2}{*}{539} & \multirow[t]{2}{*}{$55+$} & Men & \multirow[t]{2}{*}{ x-ray + symptoms } & & & 12.9 \\
\hline & & & Women & & & & 14.7 \\
\hline \multirow{3}{*}{$\begin{array}{l}\text { Finland*, } \\
1985\end{array}$} & \multirow[t]{3}{*}{13700} & \multirow[t]{3}{*}{$0+$} & Men & \multirow[t]{3}{*}{ Clinically defined OA } & & $0.5(0.3-0.6)$ & \\
\hline & & & Women & & & $1.7(1.5-1.9)$ & \\
\hline & & & Both & & & $1.1(0.9-1.3)$ & \\
\hline \multirow{3}{*}{$\begin{array}{l}\text { Finland (MFHS)*, } \\
1993\end{array}$} & \multirow{3}{*}{7220} & \multirow{3}{*}{$30+$} & Men & \multirow{3}{*}{ Clinically defined OA } & $4.1(3.6-4.6)$ & & \\
\hline & & & Women & & $6.0(5.5-6.6)$ & & \\
\hline & & & Both & & $5.1(4.6-5.6)$ & & \\
\hline \multirow{3}{*}{$\begin{array}{l}\text { Finland, } \\
\text { Haara, } 2003\end{array}$} & \multirow[t]{3}{*}{3595} & \multirow[t]{3}{*}{$30+$} & Men & \multirow{3}{*}{$\begin{array}{l}\text { Kellgren\&Lawrence, } \\
\text { grade } 2 \text { to } 4\end{array}$} & & & 41.1 \\
\hline & & & Women & & & & 50.6 \\
\hline & & & Both & & & & $\begin{array}{c}44.8 \text { and } 16.0 \\
\text { (symmetr. DIPs) }\end{array}$ \\
\hline \multirow{2}{*}{$\begin{array}{l}\text { Iceland, } \\
\text { Ingvarsson, } 1998\end{array}$} & \multirow[t]{3}{*}{1520} & \multirow[t]{2}{*}{$35+$} & Men & \multirow{2}{*}{$\begin{array}{l}\text { Kellgren\&Lawrence, } \\
\geq \text { grade } 2\end{array}$} & 12 & & \\
\hline & & & Women & & 10 & & \\
\hline $\begin{array}{l}\text { Sweden, } \\
\text { Lindberg, } 1985\end{array}$ & & & Both & $\begin{array}{l}\text { Kellgren\&Lawrence, } \\
\geq \text { grade } 2\end{array}$ & $3.1-3.6$ & & \\
\hline \multirow{2}{*}{$\begin{array}{l}\text { Sweden, } \\
\text { Bagge, } 1992\end{array}$} & \multirow[t]{2}{*}{340} & \multirow[t]{2}{*}{$75-79$} & Men & \multirow{2}{*}{$\begin{array}{l}\text { Kellgren\&Lawrence, } \\
\geq \text { grade } 2\end{array}$} & & 51.9 & 97.8 \\
\hline & & & Women & & & 59.0 & 97.1 \\
\hline $\begin{array}{l}\text { Sweden, } \\
\text { Petersson, } 1997 \\
\end{array}$ & & $35-54$ & Both & $\begin{array}{l}\text { Kellgren\&Lawrence, } \\
\geq \text { grade } 2\end{array}$ & & 10.0 & \\
\hline
\end{tabular}

* From the European Commission report on Indicators for Monitoring Musculoskeletal Problems and Conditions, 2003 (no references provided)

I 2002 var det $4 \%$ av alle uføre som hadde diagnosen artrose og diagnosen utgjorde $6,6 \%$ av alle nye uførepensjonister samme år (Rikstrygdeverket 2003).

I det omtalte Ullensakermatrialet ble artrose også kartlagt i 1994, noe som gir muligheter for å gjøre en beregning av hvor stor andel av befolkningen som rapporterer om nye tilfeller av artrose i løpet av en 10 års periode (30). Totalt 1854 personer i alderen 24 til 76 år deltok i undersøkelsen både i 1994 og 2004. Personer som rapporterte om artrose eller revmatoid artritt i 1994 ble ekskludert. De gjenværende 1675 personer rapporterte en 10-års insidens på 5,8\% (CI 4,3-7,3) for hofteartrose, 7,3\% (CI 5,7-9,0) for kneartrose og 5,6\% (CI 4,2-7,1) for håndartrose. I en svensk studie ble det i løpet av en 5 års periode funnet en insidens på 4,5\% av kneartrose og 13,6\% av håndartrose (i DIP og PIP leddene) hos personer mellom 75 og 79 år $(23,25)$. En annen svensk studie har vist at det har ikke vært noen endring i forekomst av artrose i løpet av de siste 40 år (31). I en nederlandsk studie av personer over 45 år i den generelle populasjonen, fant de at over 12 år utviklet ca. $25 \%$ av kvinnene og ca. $10 \%$ av mennene radiografisk kneartrose (32).
Insidensstudier for artrose er vanskelig å utføre både på grunn av ulike (og endrende) definisjoner av artrose, og på grunn av relativ lite samsvar mellom symptomer (som brukes for å finne nye tilfeller) og radiografiske endringer. Det kan derfor være mer relevant å se på insidensen av hofteproteseoperasjoner. I Norge ble det i 2001 operert inn litt i underkant av 7000 hofteproteser (33) og man regner med at tilnærmelsesvis $70 \%$ av hofteproteseoperasjoner skjer på bakgrunn av primær artrose (34). En islandsk studie viser økende insidens av innsetting av hofteproteser over en 14 års periode (1982-1996) (35). En økning i hofteproteseoperasjoner behøver imidlertid ikke indikere en økt insidens av artrose, men kan like mye reflektere økt tilgang til denne operasjonen.

\section{DEMOGRAFI OG KJENTE RISIKOFAKTORER}

Selv om epidemiologiske studier på artrose i generelle populasjoner for det meste har vært utført i Europa og USA, så finnes det data som bekrefter at artrose finnes over hele verden. For eksempel, en nyere studie av kinesiske kvinner viste at disse hadde høyere forekomst 
av radiografisk kneartrose enn kvinner i Framingham, Massachusetts, mens det ikke fantes slike forskjeller blant menn (36). Videre synes prevalensen av hofteartrose å være høyere i Europa og USA enn i andre deler av verden (37). En studie fant at prevalensen for radiografisk hofteartrose (Kellgren \& Lawrence grad $3-4)$ var $1 \%$ hos kvinner i Jamaica sammenlignet med 5\% hos kvinner i Storbritannia (38).

Det finnes også geografiske variasjoner i forekomst av artrose innen de skandinaviske landene (Tabell 2). For eksempel er forekomsten av radiografisk hofteartrose mye høyere i den islandske befolkningen enn i svenske populasjoner. På grunn av metodiske ulikheter bør forskjeller i både prevalens og insidens av artrose tolkes med forsiktighet. I tillegg er det ulike risikofaktorer som kan påvirke både prevalens og insidens av artrose.

De best dokumenterte risikofaktorene for utvikling av artrose er alder, kjønn, genetiske faktorer, fysisk belastning $\mathrm{i}$ arbeid eller fritid og overvekt/livsstilsfaktorer $(26,39)$. Det er stor enighet om at alder er den sterkeste risikofaktoren for artrose, og at artrose er hyppigere hos kvinner enn hos menn. Den høye insidensen av artrose hos postmenopausale kvinner tilsier at hormoner kan ha en betydelig innvirkning på denne økte forekomsten (40). Genetiske faktorer kan også være av betydning $(41,42)$.

To systematiske oversikter konkluderer nå med at det finnes økende evidens for at fysisk krevende yrker, som for eksempel gruvearbeid, er risikofaktorer for utvikling av kneartrose $(43,44)$. Grad av fysisk belastning uavhengig av yrke hadde også sterk sammenheng med kneartrose i den prospektive Framinghamstudien (45). I Norge er det funnet sterke sammenhenger mellom manuelt arbeid og uførepensjon hos pasienter med artrose (46) og stor grad av fysisk belastning i arbeidet er funnet å være risikofaktor for fremtidige hofteproteser hos artrosepasienter (34). Om fysisk belastning er en årsaksfaktor eller en prognostisk ugunstig faktor ved artrose er fremdeles ikke endelig avklart.

Livsstilsfaktorer som overvekt og inaktivitet, samt en økende andel eldre i befolkningen, kan bidra til å forklare den økende forekomsten av artrose i befolkningen (1). Mange store epidemiologiske studier har vist at overvekt er en viktig risikofaktor for kneartrose, mens sammenhengen er mer uklar for hofte- og håndartrose (39). En norsk studie fant at kroppsmasseindeks er en klar risikofaktor for fremtidige hofteproteser hos artrosepasienter (34). Risikoen for hofteproteseoperasjon var imidlertid ikke påvirket av vektendringer hos 40- og 50-åringer (47). Røyking er en annen omdiskutert livsstilsfaktor der evidensen er motstridende. Noen studier har vist at røyking kan beskytte mot kneartrose (48) og håndartrose (49) mens andre finner ingen sammenheng mellom røyking og artrose $(30,50)$. Det trenges flere gode studier for å dokumentere betydningen av de fleste omtalte livsstilsfaktorenes sammenheng med utvikling av artrose, spesielt med tanke på utvikling av hofte- og håndartrose.

\section{MORTALITET OG KOMORBIDITET}

Konsekvensene av artrose er sjelden dødelig, men personer med artrose rapporterer om mye smerter, stivhet og tretthet og mange problemer med å fungere i dagliglivet (22,51-53). Flere store undersøkelser har også vist at artrose synes å være et komplekst syndrom med kronisk smerte, dårlig helse, og følelsesmessig uro (distress) (52,54-56). En norsk undersøkelse har vist at pasienter med håndartrose faktisk har like mye og tildels større smerteplager enn pasienter med leddgikt (11). Det er også vist lengre varighet av en sykemeldingsepisode for artrose, enn for noen annen muskelskjelettlidelse (57).

\section{BEHANDLiNG}

Behandling av artrose er sammensatt, og det finnes både nasjonale og internasjonale anbefalinger (58-61). Figur 4 viser en pyramidebasert modell for artrose som tar utgangspunkt $\mathrm{i}$ at noen tiltak bør gis til alle pasienter med artrose, mens andre tiltak som medikamentell behandling og hjelpemidler, og spesielt kirurgiske tiltak, skal bare gis til noen få pasienter. Figuren viser at informasjon til pasienten, spesielt om betydningen av vektkontroll, evt. vektreduksjon, og trening/fysisk aktivitet, er basis i enhver behandling av pasienter med artrose. Videre, noen kan også trenge råd og tilrettelegging av hjelpemidler for å avlaste affisert(e) ledd, samt medikamentell behandling. Basisinformasjon og andre såkalte ikke-medikamentelle tiltak kan gis til pasienten individuelt eller i gruppebaserte artroseskoleprogram. Tverrfaglige behandlingsprogram anbefales $\mathrm{i}$ internasjonale retningslinjer for pasienter med artrose (59-61).

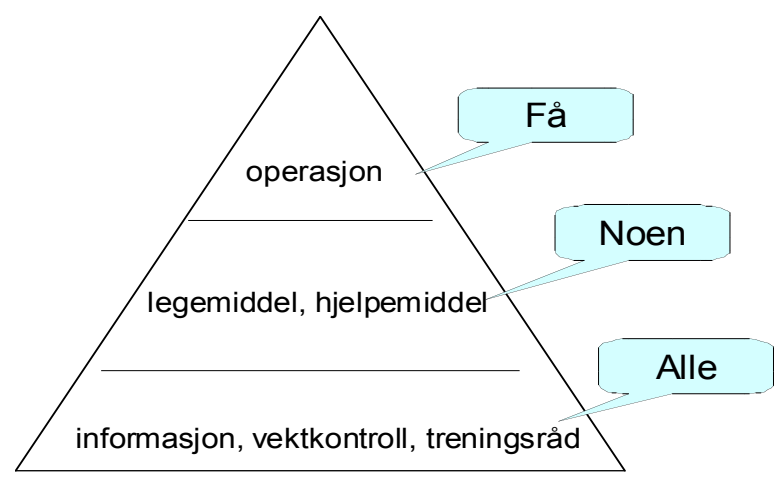

Figur 4. Behandling av artrose.

Paracetamol er fremdeles førstevalg av preparat etterfulgt av tradisjonelle NSAIDS, eventuelt spesifikke COX 2 hemmere ved medikamentell behandling. Sterkere smertestillende medisiner kan også være aktuelt, evt. injeksjoner i inflammerte ledd (f.eks. glucorticoider, sjeldent hyaluronsyre i.a. i store ledd). De nyeste (europeiske) terapianbefalinger tilrår dess- 
uten bruk av NSAIDS gel lokalt og nevner SYSADOA (systemic slow acting drugs against osteoarthritis), som for eksempel glucosaminsulfat/hydroklorid, chondroitinsulfat, ASU (Avocado Soybean Unsaponifiable) og Diacerin (59-61).

Man bør være oppmerksom på at de fleste kliniske studiene er på kneartrose. I mangel av studier på håndog hofteartrose overføres noen av anbefalingene fra kneartrose til andre leddregioner. Så langt har man ikke lykkes i å identifisere sykdomsmodifiserende medikamenter (DMOADS). Det forskes i dag spesielt på bl.a. hemming av pro-inflammatoriske cytokiner $(4,12,62)$.

\section{KIRURGI}

Kirurgisk behandling er et behandlingstilbud senere i sykdomsforløpet for et fåtall av pasienter med artrose. Kirurgisk behandling innebærer oftest artroplastiske inngrep og/eller proteseroperasjoner, for eksempel interposijonsplastikk, avstiving av CMC-ledd, avstivning av MTP1 og avstivning av håndledd. Proteser finnes i mangfoldige versjoner, som del- og helproteser, i sementert eller usementert form for de fleste ledd (f.eks. skulder, albue, hofte, kne, ankel). Ved hofteartrose brukes storsett hele proteser og i kneet unikondylære eller totalproteser avhengig av pasientens individuelle status. Det norske leddproteseregisteret registrerer klinisk informasjon om alle proteseoperasjoner i Norge $(33,63)$.

Ved mindre lokale skader kan operativ behandling variere fra artroskopiske inngrep (f.eks. fjerning av menisk) til brusktransplantasjon (f.eks. mosaikkplastikk) (64).

\section{AVSLUTTENDE KOMMENTAR}

Økningen av artrose i befolkningen har medført økt oppmerksomhet omkring denne sykdommen, og forståelsen av artrose har endret seg med økt kunnskap. Allikevel er kunnskapen om artrose sannsynligvis ennå i sin spede barndom. Med flere eldre samt en moderne livsstil er det rimelig å anta at artrose vil bli et større folkehelseproblem i fremtiden enn det vi ser i dag ikke nødvendigvis fordi artrose er en manifestasjon av aldring, men fordi forskningsbasert kunnskap tar år å utvikle og enda lengre tid å implementere $\mathrm{i}$ praksis. Man kan derfor håpe på at artrose kan bli et høyt prioritert område for videre forskning, og at ny kunnskap vil kunne gi verdifulle bidrag til forebygging og behandling $i$ fremtiden.

\section{REFERANSER}

1. Ehrlich GE. The rise of osteoarthritis. Bull World Health Organ 2003; 81 (9): 630.

2. Hinton R, Moody RL, Davis AW, Thomas SF. Osteoarthritis: diagnosis and therapeutic considerations. Am Fam Physician 2002; 65 (5): 841-8.

3. Berenbaum F. Signaling transduction: target in osteoarthritis. Curr Opin Rheumatol 2004; 16 (5): 616-22.

4. Goldring MB. Update on the biology of the chondrocyte and new approaches to treating cartilage diseases. Best Pract Res Clin Rheumatol 2006; 20 (5): 1003-25.

5. Rogers J, Watt I, Dieppe P. Arthritis in Saxon and mediaeval skeletons. BMJ 1981; 283 (6307): 1668-70.

6. Altman RD, Bloch DA, Bole GG, Jr, Brandt KD, Cooke DV, Greenwald RA et al. Development of clinical criteria for osteoarthritis. J Rheumatol 1987; 14 (Spec No): 3-6.

7. Dieppe P. Osteoarthritis: time to shift the paradigm. This includes distinguishing between severe disease and common minor disability. BMJ 1999; 318 (7194): 1299-300.

8. Altman RD, Gray R. Inflammation in osteoarthritis. Clin Rheum Dis 1985; 11 (2): 353-65.

9. Birrell F, Arden NK, Conaghan PG, Cooper C, Dieppe P, Doherty M. Is it time for more rheumatologists to embrace osteoarthritis? Rheumatology 2005; 44 (7): 829-30.

10. Brooks PM. The burden of musculoskeletal disease - a global perspective. Clin Rheumatol 2006; 25 (6): 778 81.

11. Slatkowsky-Christensen B, Mowinckel P, Loge JH, Kvien TK. Health-related quality of life in women with symptomatic hand osteoarthritis: A comparison with rheumatoid arthritis patients, healthy controls, and normative data. Arthritis Rheum 2007; 57 (8): 1404-9.

12. Steinmeyer J. Cytokines in osteoarthritis - current status on the pharmacological intervention. Front Biosci 2004; 9: 575-80.

13. Altman R, Asch E, Bloch D, Bole G, Borenstein D, Brandt K et al. Development of criteria for the classification and reporting of osteoarthritis. Classification of osteoarthritis of the knee. Diagnostic and Therapeutic Criteria Committee of the American Rheumatism Association. Arthritis Rheum 1986; 29 (8): 1039-49.

14. Altman R, Alarcon G, Appelrouth D, Bloch D, Borenstein D, Brandt K et al. The American College of Rheumatology criteria for the classification and reporting of osteoarthritis of the hand. Arthritis Rheum 1990; 33 (11): 1601-10. 
15. Altman R, Alarcon G, Appelrouth D, Bloch D, Borenstein D, Brandt K et al. The American College of Rheumatology criteria for the classification and reporting of osteoarthritis of the hip. Arthritis Rheum 1991; 34 (5): 505-14.

16. Kellgren JH, Lawrence JS. Radiological assessment of osteo-arthrosis. Ann Rheum Dis 1957; 16 (4): $494-502$.

17. Petersson IF, Boegard T, Saxne T, Silman AJ, Svensson B. Radiographic osteoarthritis of the knee classified by the Ahlback and Kellgren \& Lawrence systems for the tibiofemoral joint in people aged 35-54 years with chronic knee pain. Ann Rheum Dis 1997; 56 (8): 493-6.

18. Altman RD, Hochberg M, Murphy WA, Jr, Wolfe F, Lequesne M. Atlas of individual radiographic features in osteoarthritis. Osteoarthritis Cartilage 1995; 3 (Suppl A): 3-70.

19. Altman RD, Gold GE. Atlas of individual radiographic features in osteoarthritis, revised. Osteoarthritis Cartilage 2007; 15 (Suppl A): 1-56.

20. Dougados M, Nakache JP, Gueguen A. Criteria for generalized and focal osteoarthritis. Rev Rhum Engl Ed 1996; 63 (9): 569-75.

21. Holte HH, Tambs K, Bjerkedal T. Time trends in disability pensioning for rheumatoid arthritis, osteoarthritis and soft tissue rheumatism in Norway 1968-97. Scand J Public Health 2003; 31 (1): 17-23.

22. Grotle M, Hagen KB, Natvig B, Dahl FA, Kvien TK. Prevalence and burden of osteoarthritis: results from a population survey in Norway. $J$ Rheumatol 2008; 35 (4) (In press).

23. Bagge E, Bjelle A, Svanborg A. Radiographic osteoarthritis in the elderly. A cohort comparison and a longitudinal study of the "70-year old people in Goteborg". Clin Rheumatol 1992; 11 (4): 486-91.

24. Bagge E, Bjelle A, Valkenburg HA, Svanborg A. Prevalence of radiographic osteoarthritis in two elderly European populations. Rheumatol Int 1992; 12 (1): 33-8.

25. Petersson IF, Boegard T, Saxne T, Silman AJ, Svensson B. Radiographic osteoarthritis of the knee classified by the Ahlback and Kellgren \& Lawrence systems for the tibiofemoral joint in people aged 35-54 years with chronic knee pain. Ann Rheum Dis 1997; 56 (8): 493-6.

26. Petersson IF, Jacobsson LT. Osteoarthritis of the peripheral joints. Best Pract Res Clin Rheumatol $2002 ; 16$ (5): 741-60.

27. Lindberg H, Nilsson BE. Coinciding morbidity in patients with coxarthrosis. An epidemiological study of roentgen examinations. Arch Orthop Trauma Surg 1985; 104 (2): 82-4.

28. Ingvarsson T, Hagglund G, Lohmander LS. Prevalence of hip osteoarthritis in Iceland. Ann Rheum Dis 1999; 58 (4): 201-7.

29. Oliveria SA, Felson DT, Reed JI, Cirillo PA, Walker AM. Incidence of symptomatic hand, hip, and knee osteoarthritis among patients in a health maintenance organization. Arthritis Rheum 1995; 38 (8): 1134-41.

30. Grotle M, Hagen KB, Natvig B, Dahl FA, Kvien TK. Overweight and osteoarthritis in knee, hip and/or hand: Results from an epidemiological study with 10 years follow-up. J Rheumatol (In press).

31. Danielsson L, Lindberg H. Prevalence of coxarthrosis in an urban population during four decades. Clin Orthop Relat Res 1997; (342): 106-10.

32. Schouten JS, van den Ouweland FA, Valkenburg HA. A 12 year follow up study in the general population on prognostic factors of cartilage loss in osteoarthritis of the knee. Ann Rheum Dis 1992; 51 (8): 932-7.

33. Furnes O, Havelin LI, Espehaug B, Engesaeter LB, Lie SA, Vollset SE. [The Norwegian registry of joint prostheses -15 beneficial years for both the patients and the health care]. Tidsskr Nor Laegeforen $2003 ; 123$ (10): 1367-9.

34. Flugsrud GB, Nordsletten L, Espehaug B, Havelin LI, Meyer HE. Risk factors for total hip replacement due to primary osteoarthritis: a cohort study in 50,034 persons. Arthritis Rheum 2002; 46 (3): 675-82.

35. Ingvarsson T, Hagglund G, Jonsson H, Jr, Lohmander LS. Incidence of total hip replacement for primary osteoarthrosis in Iceland 1982-1996. Acta Orthop Scand 1999; 70 (3): 229-33.

36. Zhang Y, Xu L, Nevitt MC, Aliabadi P, Yu W, Qin M et al. Comparison of the prevalence of knee osteoarthritis between the elderly Chinese population in Beijing and whites in the United States: The Beijing Osteoarthritis Study. Arthritis Rheum 2001; 44 (9): 2065-71.

37. Croft P. The occurrence of osteoarthritis outside Europe. Ann Rheum Dis 1996; 55 (9): 661-4.

38. Lawrence JS, Molyneux M. Degenerative joint disease among populations in Wensleydale, England and Jamaica. Int J Biometeorol 1968; 12 (2): 163-75.

39. Hochberg M. Osteoarthritis. In: Silman A, Hochberg M, eds. Epidemiology of the Rheumatic Diseases, 2nd edn. Oxford: Oxford University Press, 2007: 205-29.

40. van Saase JL, van Romunde LK, Cats A, Vandenbroucke JP, Valkenburg HA. Epidemiology of osteoarthritis: Zoetermeer survey. Comparison of radiological osteoarthritis in a Dutch population with that in 10 other populations. Ann Rheum Dis 1989; 48: 271-80.

41. Ushiyama T, Ueyama H, Inoue K, Nishioka J, Ohkubo I, Hukuda S. Estrogen receptor gene polymorphism and generalized osteoarthritis. J Rheumatol 1998; 25 (1): 134-7.

42. Loughlin J. Genetic epidemiology of primary osteoarthritis. Curr Opin Rheumatol 2001; 13 (2): 111-6. 
43. Felson DT, Lawrence RC, Hochberg MC, McAlindon T, Dieppe PA, Minor MA et al. Osteoarthritis: new insights. Part 2: treatment approaches. Ann Intern Med 2000; 133 (9): 726-37.

44. Lievense A, Bierma-Zeinstra S, Verhagen A, Verhaar J, Koes B. Influence of work on the development of osteoarthritis of the hip: a systematic review. J Rheumatol 2001; 28 (11): 2520-8.

45. McAlindon TE, Wilson PW, Aliabadi P, Weissman B, Felson DT. Level of physical activity and the risk of radiographic and symptomatic knee osteoarthritis in the elderly: the Framingham study. Am J Med $1999 ; 106$ (2): 151-7.

46. Holte HH, Tambs K, Bjerkedal T. Manual work as predictor for disability pensioning with osteoarthritis among the employed in Norway 1971-1990. Int J Epidemiol 2000; 29 (3): 487-94.

47. Flugsrud GB, Nordsletten L, Espehaug B, Havelin LI, Meyer HE. Weight change and the risk of total hip replacement. Epidemiology 2003; 14 (5): 578-84.

48. Sandmark H, Hogstedt C, Lewold S, Vingard E. Osteoarthrosis of the knee in men and women in association with overweight, smoking, and hormone therapy. Ann Rheum Dis 1999; 58 (3): 151-5.

49. Haara MM, Manninen P, Kroger H, Arokoski JP, Karkkainen A, Knekt P et al. Osteoarthritis of finger joints in Finns aged 30 or over: prevalence, determinants, and association with mortality. Ann Rheum Dis 2003 ; 62 (2): $151-8$.

50. Hart DJ, Doyle DV, Spector TD. Incidence and risk factors for radiographic knee osteoarthritis in middleaged women: the Chingford Study. Arthritis Rheum 1999; 42 (1): 17-24.

51. Birrell F, Croft P, Cooper C, Hosie G, Macfarlane GJ, Silman A. Radiographic change is common in new presenters in primary care with hip pain. PCR Hip Study Group. Rheumatology 2000; 39 (7): 772-5.

52. Croft P, Lewis M, Wynn JC, Coggon D, Cooper C. Health status in patients awaiting hip replacement for osteoarthritis. Rheumatology 2002; 41 (9): 1001-7.

53. Dawson J, Linsell L, Zondervan K, Rose P, Carr A, Randall T et al. Impact of persistent hip or knee pain on overall health status in elderly people: a longitudinal population study. Arthritis Rheum 2005; 53 (3): 368-74.

54. Thomas E, Peat G, Harris L, Wilkie R, Croft PR. The prevalence of pain and pain interference in a general population of older adults: cross-sectional findings from the North Staffordshire Osteoarthritis Project (NorStOP). Pain 2004; 110 (1-2): 361-8.

55. Fautrel B, Hilliquin P, Rozenberg S, Allaert FA, Coste P, Leclerc A et al. Impact of osteoarthritis: results of a nationwide survey of 10,000 patients consulting for OA. Joint Bone Spine 2005; 72 (3): 235-40.

56. Kadam UT, Jordan K, Croft PR. Clinical comorbidity in patients with osteoarthritis: a case-control study of general practice consulters in England and Wales. Ann Rheum Dis 2004; 63 (4): 408-14.

57. Brage S, Nygard JF, Tellnes G. The gender gap in musculoskeletal-related long-term sickness absence in Norway. Scand J Soc Med 1998; 26 (1): 34-43.

58. SLV Statens Legemiddelverk. Terapianbefaling: Behandling av artrose. 2004.

59. Zhang W, Doherty M, Arden N, Bannwarth B, Bijlsma J, Gunther KP et al. EULAR evidence based recommendations for the management of hip osteoarthritis: report of a task force of the EULAR Standing Committee for International Clinical Studies Including Therapeutics (ESCISIT). Ann Rheum Dis 2005 ; 64 (5): 669-81.

60. Zhang W, Doherty M, Leeb BF, Alekseeva L, Arden NK, Bijlsma JW et al. Eular evidence based recommendations for the management of hand osteoarthritis - report of a task force of the Eular Standing Committee for International Clinical Studies Including Therapeutics (ESCISIT). Ann Rheum Dis 2007; 66 (3): 377-88.

61. Jordan KM, Arden NK, Doherty M, Bannwarth B, Bijlsma JW, Dieppe P et al. EULAR Recommendations 2003: an evidence based approach to the management of knee osteoarthritis: Report of a Task Force of the Standing Committee for International Clinical Studies Including Therapeutic Trials (ESCISIT). Ann Rheum Dis 2003; 62 (12): 1145-55.

62. Goldberg SH, Von Feldt JM, Lonner JH. Pharmacologic therapy for osteoarthritis. Am J Orthop 2002; 31 (12): 673-80.

63. Arthursson AJ, Furnes O, Espehaug B, Havelin LI, Soreide JA. Validation of data in the Norwegian Arthroplasty Register and the Norwegian Patient Register: 5,134 primary total hip arthroplasties and revisions operated at a single hospital between 1987 and 2003. Acta Orthop 2005; 76 (6): 823-8.

64. Bartha L, Vajda A, Duska Z, Rahmeh H, Hangody L. Autologous osteochondral mosaicplasty grafting. $J$ Orthop Sports Phys Ther 2006; 36 (10): 739-50. 